\title{
PEMBERIAN PENGUATAN POSITIF OLEH GURU DALAM UPAYA MENINGKATKAN MOTIVASI BELAJAR SISWA PADA KOMPETENSI DASAR HUBUNGAN SATUAN PANJANG PELAJARAN MATEMATIKA KELAS I SDN 060819 MEDAN KOTA
}

\author{
Onike Naibaho
}

Surel: onikenaibaho@gmail.com

\begin{abstract}
ABSTRAK
Penelitian ini bertujuan untuk meningkatkan motivasi belajar siswa pada kompetensi dasar hubungan satuan panjang pelajaran matematika kelas VI SD Negeri 060819 Medan Kota. Populasi penelitian ini dilakukan terhadap seluruh peserta didik Kelas VI di SD Negeri 060819 Medan Kota. Berjumlah 44 orang, dengan menggunakan penguatan positif (hadiah). Penelitian ini dilakukan untuk bidang studi Matematika Pokok Bahasan "Hubungan Satuan Panjang". Alat yang dilakukan untuk mengumpulkan data dalam penelitian ini adalah lembar observasi untuk guru, lembar observsi motivasi siswa dan daftar nilai siswa. Hasil penelitian menunjukkan bahwa pada kondisi awal, nilai rata-rata hitung siswa adalah 5,70 pada siklus I nilai rata-rata hitung siswa naik yaitu 6,02 sedangkan pada siklus II terjadi kenaikan yang sangat signifikan, nilai rata-rata siswa naik menjadi 8,81.
\end{abstract}

Kata Kunci: Motivasi Belajar, Penguatan Positif, Lembar Observasi

\section{PENDAHULUAN}

Hakikat matematika adalah pengetahuan tentang bilangan dan kalkulasi, matematika adalah pengetahuan tentang logika dan berhubungan dengan bilangan. Matematika dipelajari mempunyai tujuan bagi peserta didik yaitu mempersiapkan siswa agar dapat menggunakan matematika dan pola pikir matematika dalam kehidupan sehari-hari dalam mempelajari ilmu pengetahuan.

Menghadapi hal masalah tersebut, perlulah guru melakukan sesuatu, dengan mengoptimalkan motivasi yang tinggi pada peserta didik, memberi semangat dan mengaktifkan siswa supaya tetap berminat dan siaga, mau memusatkan perhatian pada tugas-tugas matematika. Adanya beberapa siswa yang mempunyai masalah dalam belajarnya seperti siswa malas belajar, acuh tak acuh, tidak bersemangat beraktifitas belajar matematika untuk memperbesar peranan peserta didik dalam aktifitas pengajaran perlu memberikan penguatan. Memberikan penguatan merupakan suatu keterampilan yang digunakan untuk memberikan umpan balik pada siswa bentuk kata-kata (verbal maupun non verbal). Tujuannya untuk meningkatkan motivasi belajar siswa dalam kegiatan belajar mengajar dan meningkatkan berulangnya kembali

SD Negeri 060819 Medan Kota 
perbuatan positif atau aktif dalam belajar.

Siswa akan terdorong menyukai pelajaran matematika bila merasakan adanya kebutuhan terhadap pelajaran itu sehingga timbul usaha yang tinggi dalam belajar dan berprestasi. Siswa yang mendapat nilai bagus bila diberikan pujian akan merasa senang dan meningkatkan motivasinya dalam belajar serta jika ada siswa yang kurang rajin/malas belajar juga bisa diberi penguatan agar merasa terdorong dalam belajar misal dengan perkataan "coba, kamu pasti bisa" atau guru mengatakan sebagai penghargaan kepada siswasiswanya "anak-anak siapa yang selesai secara cepat dan benar akan ibu beri buku tulis". Buku tulis dalam hal ini adalah bentuk penghargaan terhadap hasil karya siswa sebelum mereka bekerja. Tetapi pada saat terjadi aktivitas belajar yang real di sekolah adalah para guru kurang memperhatikan peserta didiknya di kelas, bahkan mereka sering mengabaikan pemberian penguatan atas pekerjaan, partisipasi dan ekspresi siswa dalam aktivitas belajar mengajar.

Sebagaimana yang telah diuraikan di dalam latar belakang masalah di atas, maka dapat diidentifikasi masalah dalam penelitian yaitu sebagai berikut: a. Rendahnya motivasi siswa pada aktVIitas pembelajaran matematika.

b. Prestasi belajar siswa yang rendah pada pembelajaran matematika.

c. Guru jarang memberikan penguatan positif sebagai penghargaan berupa hadiah pada pembelajaran matematika.

Adapun tujuan dari penelitian ini adalah untuk:

a. Mengetahui pemberian penguatan positif pada pembelajaran matematika di Kelas VI.

b. Mengetahui upaya yang digunakan dalam meningkatkan motivasi berprestasi siswa.

\section{METODE PENELITIAN}

Jenis penelitian ini adalah Penelitian Tindakan Kelas (PTK). Dimana penelitian ini berupaya memaparkan pengaruh pemberian penguatan positif (hadiah) terhadap motivasi berprestasi siswa pada mata pelajaran matematika di Kelas VI SD Negeri 060819 Medan Kota.

Yang menjadi subyek dalam penelitian ini adalah siswa Kelas VI SD Negeri 060819 Medan Kota berjumlah 44 orang. Desain penelitian yang dilaksanakan adalah desain yang menggunakan model Kemmis dan Mc. Taggart yang dikemukakan secara skematis.

Sesuai dengan jenis penelitian ini, yaitu penelitian tindakan kelas maka penelitian ini memiliki 
Oike Naibaho: Pemberian Penguatan Positif ..

beberapa tahap pelaksanaan tindakan yakni dua siklus dimana setiap siklusnyamempunyai empat tahap yang akan dijelaskan sebagai berikut:

Kegiatan pada yang dilakukan dalam perencanaan siklus I adalah:

a. Melakukan observasi awal untuk menemukan model dan format penerapan tindakan pada siklus I.

b. Menyusun rencana pembelajaran untuk setiap pertemuan yang memuat skenario pembelajaran dengan pemberian penguatan.

c. Guru memaparkan materi ajar, dan menjelaskan pengukuran satuan panjang.

d. Guru melakukan evaluasi setelah materi dijelaskan.

e. Menanggapi hasil kerja siswa dan memberikan penguatan agar siswa termotivasi untuk aktivitas belajar berikutnya.

Kegiatan yang dilaksanakan dalam tahap pelaksaan tindakan ini adalah melaksanakan tindakan sesuai dengan yang telah direncanakan, berupa proses pembelajaran sesuai dengan rencana pelaksanaan pembelajaran. Pelaksanaan berlangsung 2 kali pertemuan.

Observasi yang dilaksanakan meliputi implementasi dalam monitoring pada proses pembelajaran matematika di kelas secara langsung. Kegiatan yang diamati meliputi aktifitas guru dan siswa dalam proses pembelajaran. Pengamatan ini bertujuan untuk mengetahui kesesuaian tindakan dengan rencana yang telah disusun dan guna mengetahui sejauh mana pelaksanaan tindakan dapat menghasilkan perubahan yang sesuai dengan hasil yang dikehendaki.

Kegiatan refleksi dilakukan untuk mempertimbangkan pedoman mengajar yang dilakukan serta melihat kesesuaian yang dicapai dengan yang diinginkan dalam pembelajaran matematika, untuk itu melakukan refleksi atas adanya kelemahan/ kekurangan tindakan yang telah dilakukan yang berguna memperbaiki pelaksanaan pada siklus berikut (Siklus II).

Pada siklus II akan dilaksanakan 4 (empat) tahapan. Prosedurnya sama dengan siklus I dan pembelajaran dilakukan dengan memperbaiki kekurangan yang ditemukan pada siklus I. Dimana pada tahapan ini pelaksanaan diawali dengan proses belajar mengajar dengan kegiatan yang dilakukan dalam perencanaan masih sama yaitu:

a. Melakukan observasi awal untuk menemukan model dan format penerapan tindakan pada siklus II.

b. Menyusun rencana pembelajaran untuk setiap pertemuan yang memuat skenario pembelajaran dengan pemberian penguatan. 
c. Guru memaparkan materi ajar, dan menjelaskan pengukuran satuan panjang.

d. Guru memberikan soal latihan setelah materi dijelaskan.

e. Menanggapi hasil kerja siswa dan memberikan penguatan agar siswa termotivasi untuk aktivitas belajar berikutnya.

Penelitian melakukan kegiatan yang sama pada siklus I tetapi dilakukan setelah ada perbaikan. Tahap pelaksanaan siklus II yaitu:

a. Peneliti menjelaskan materi mengenai hubunganantar satuan panjang kepada siswa Kelas VI.

b. Memberikan kesempatan bertanya bagi siswa yang kurang memahami materi.

c. Mengadakan evaluasi dengan memberi soal isian sebanyak 10 soal.

d. Melakukan penilaian tugas yang siswa selesaikan.

e. Melakukan refleksi dimana siswa dapat mengetahui jawaban mereka benar dan memperbaiki jawaban mereka yang salah.

f. Memberikan penguatan positif berupa hadiah kepada 3 orang mendapat nilai 10 dan 3 orang yang mendapat nilai 9 .

\begin{tabular}{llr}
\multicolumn{1}{c}{ Pada waktu } & melakukan \\
tindakan, peneliti & melakukan \\
observasi & untuk mengetahui tingkat \\
motivasi & belajar siswa, perhatian \\
siswa terhadap pembelajaran
\end{tabular}

matematika, partisipasi dalam kegiatan pembelajaran dan keantusiasan terhadap materi yang diajarkan.

Kegiatan ini mencoba untuk melihat hasil perkembangan pelaksanaan dan memuat kesimpulan mengenai kekurangan atau kelebihan selama proses pemberian penguatan pada kegiatan belajar mengajar. Refleksi dilakukan untuk mengetahui ada tidaknya peningkatan motivasi belajar dari tindakan yang telah dilakukan.

Untuk pengumpulan data
dalam penelitian ini, teknik
pengumpulan data yang akan
digunakan berpedoman pada
paradigma penelitian kualitatif.
Ekowati dan Mulayani (2003:7) serta Soedarsono (2001:25) menyatakan penelitian bersifat kualitatif yaitu penelitian dimana data yang dikumpulkan dalam bentuk simbol seperti pernyataan-pernyataan dan perasaan. Sedangkan penelitian kuantitatif adalah penelitian yang datanya dilambangkan dengan simbol matematika yang berupa angkaangka.

Alat pengumpulan data menurut Stringer (1999) dapat dilakukan melalui: (1) observasi, (2) wawancara, (3) dokumen, media dan peralatan, dan (4) rekaman informasi. Sedangkan alat yang digunakan antara lain: (1) pedoman pengamatan, (2) catatan lapangan dan annecdotal 
records, (3) analisis dokumen dan (4) perekam suara dan gambar (Ekowati dan Mulayani:10).

Dalam pengumpulan data selama proses pembelajaran berlangsung, dibantu juga oleh observer yaitu guru kelas VI di sekolah tersebut. Adapun perannya adalah mengamati aktifitas pembelajaran yang berpedoman pada lembar observasi yang telah disiapkan. Observasi dimaksudkan untuk mengetahui kesesuaian tindakan dengan rencana yang disusun dan untuk mengetahui sejauh mana pelaksanaan tindakan dapat menghasilkan perubahan yang sesuai dengan yang dikehendaki.

Tes awal diberikan untuk mengetahui tingkat pemahaman siswa terhadap pembelajaran matematika. Tes diberikan pada setiap siklus untuk memperoleh data tentang peningkatan motivasi belajar siswa.

Analisis data yang dilakukan dalam penelitian ini berupa:

a. Melakukan pemeriksaan data yang sudah masuk.

b. Melakukan penafsiran

c. Menyimpulkan apakah tindakan pembelajaran ini terjadi peningkatan motivasi belajar siswa atau tidak berdasarkan hasil observasi.

d. Tahap tindak lanjut yaitu merumuskan langkah-langkah perbaikan untuk siklus pembelajaran berikutnya. e. Pengambilan keputusan.

Adapun kriteria evaluasi
tentang berhasil atau tidaknya
tindakan setelah melihat beberapa
dari indikator ini dimiliki oleh siswa:

a. Puas terhadap nilai sebagai hasil usaha sendiri.

b. Ciri-ciri prilaku belajar :

- Kreatif

- Lebih gigih

- Energik

- Suka bertindak

- Produktif

- Penuh inisiatif

- Lebih tangguh dalam mengerjakan suatu tugas

c. Menyukai tugas-tugas yang menantang.

d. Bertanggung jawab terhadap tugas yang diberikan.

e. Suka berinteraksi dengan orangorang.

f. Selalu menyelesaikan tugas lebih cepat.

g. Memiliki usaha yang sangat menonjol.

h. Tidak suka membuang-buang waktu.

i. Memiliki semangat yang tinggi.

j. Tidak cepat putus asa.

k. Selalu mempertahankan pendapat yang dianggapnya benar.

1. Tidak menyelesaikan tugas setengah-setengah.

Kriteria untuk menentukan pe ringkat dari indikator motivasi 
berprestasi yang dibagi menjadi 5 yaitu:

a. Sangat baik : $80 \%$ - $100 \%$ dari jumlah indikator yang ada.

b. Baik : $60 \%$ - 79\% dari jumlah indikator yang ada.

c. Cukup: $40 \%$ - $59 \%$ dari jumlah indikator yang ada.

d. Kurang: $20 \%$ - 39\% dari jumlah indikator yang ada.

e. Sangat kurang: $0 \%-19 \%$ dari jumlah indikator yang ada.

Kriteria untuk menentukan keberhasilan nilai siswa dibagi menjadi 2 yaitu :

a. Nilai $7-10=$ Berhasil

b. Nilai $0-6=$ Belum Berhasil

Analisa ini dilakukan untuk mengetahui berhasil atau tidaknya tindakan yang dilakukan dalam penelitian ini. Hal ini dilihat dari seberapa persenkah tingkat keberhasilan yang dicapai dilihat dari perubahan menyerap pelajaran.

Dengan rumus :

$$
P=\frac{f}{n} x 100 \%
$$

Dimana :

$\mathrm{p}=$ angka prestasi

$\mathrm{f}=$ jumlah siswa yang mengalami perubahan

$\mathrm{n}=$ jumlah seluruh siswa

\section{HASIL DAN PEMBAHASAN}

Langkah pertama yang dilakukan oleh guru pada siklus I adalah melakukan penjajakan atau identifikasi terhadap masalah yang akan diteliti dengan melakukan tes awal pada saat siswa berada di dalam kelas dengan menggunakan alat bantu Daftar Ceklist untuk melihat gejala motivasi berprestasi siswa yang ditandai dalam bentuk tingkat kreatifitasnya, kegigihan dalam mengerjakan tugas, produktifitas maupun inisiatif siswa dalam mengerjakan tugas, tingkat kecepatan siswa dalam menyelesaikan tugas, tingkat interaksi siswa dengan orang lain.

Dari hasil tes awal untuk konsep hubungan satuan panjang dalam bentuk tes isian sebanyak 10 soal. Dari hasil tes awal pada tabel 1 di atas tergambar bahwa dari 44 siswa Kelas VI SD Negeri 060819 Medan Kota, 33 orang siswa atau $75 \%$ belum mencapai nilai ketuntasan belajar yaitu nilai $\geq 7$ berarti belum mencapai kompetensi dasar konsep pengukuran sedangkan telah mencapai batas ketuntasan yaitu memperoleh nilai $\geq$ 7 sebanyak 11 orang siswa atau $25 \%$ saja dengan nilai rata-rata kelas 5,70.

Kelas yang diobservasi dengan menggunakan daftar chek list adalah siswa Kelas VI SD Negeri 060819 Medan Kota, dan berdasarkan hasil daftar chek list, hampir rata-rata siswa memiliki motivasi berprestasi yang rendah untuk tiap indikator yang telah ditetapkan. 
Dari data hasil observasi di atas dapat diketahui bahwa motivasi belajar siswa kelas I bisa dikatakan masih rendah, hal ini dapat dilihat dari:

a. Hanya ada 1 indikator untuk kriteria baik atau sebesar 5,54\% dari 18 indikator yang ada.

b. Ada 3 indikator untuk kriteria kurang atau sebesar 16,65\% dari 18 indikator yang ada.

c. Ada 14 indikator untuk kriteria sangat kurang atau sebesar $31,81 \%$ dari 18 indikator yang ada.

Berdasarkan hasil di atas, maka peneliti berencana untuk melakukan penelitian tindakan kelas yang mengimplementasikan bimbingan belajar dengan melakukan perbaikan cara pengajaran.

Pada kegiatan ini peneliti merefleksi dan mengevaluasi semua tahap kegiatan yang telah dilakukan mulai dari pelaksanaan kegiatan tindakan hingga observasi.

Dari observasi guru yang menggunakan metode penguatan positif berupa hadiah pada siklus I di atas, dapat dilihat :

a. Ada 2 indikator guru yang memperoleh nilai D dari 6 indikator yang ada, yaitu pada indikator menggunakan macammacam penguatan positif verbal dan menggunakan macam-macam penguatan positif non verbal. b. Ada 4 indikator yang memperoleh nilai $\mathrm{C}$ dari 6 indikator yang ada, yaitu dapat memberikan penguatan positif dengan segera, memilih hadiah yang sederhana dan bermanfaat untuk kelangsungan belajar siswa, diberikan secara sederhana dan tidak mahal, dan dapat menyajikan konsep matematika dengan baik.

Dari lembar observasi guru pada tabel 4, dapt ditarik kesimpulan bahwa guru kurang memfungsikan metode pemberian penguatan positif.

Dari data hasil observasi pada siklus I di atas dapat diketahui bahwa siswa Kelas VI bisa dibilang hasil belajar dari indikator yang telah ditentukan masih rendah, hal ini dapat dilihat dari :

a. Ada 1 indikator yang masuk kriteria sangat baik atau sebesar $5,55 \%$ dari 18 indikator yang ada. Jumlah indikator mengalami peningkatan pada kriteria ini dari awal kegiatan observasi sebelum dilakukan tindakan. Jadi jumlah siswa yang mengalami perubahan cukup meningkat yaitu menjadi 37 orang atau naik sekitar $6,82 \%$ untuk indikator bertanggung jawab terhadap tugas yang diberikan.

b. Ada 2 indikator untuk kriteria cukup atau sekitar $11,11 \%$ dari 18 indikator yang ada. Jumlah indikator mengalami peningkatan 
pada kriteria ini dari awal kegiatan observasi sebelum dilakukan tindakan. Jumlah siswa yang mengalami perubahan cukup meningkat dari sebelum tindakan yaitu 20 siswa atau naik sekitar $22,73 \%$ untuk indikator kreatif, ada 22 siswa atau naik sekitar 40,91\% untuk indikator Energik.

c. Ada 6 indikator untuk kriteria kurang atau sekitar 33,33\% dari 18 indikator yang ada. Jumlah indikator mengalami peningkatan pada kriteria ini dari awal kegiatan observasi sebelum dilakukan tindakan. Jumlah siswa yang mengalami perubahan cukup meningkat dari sebelum tindakan yaitu 16 siswa atau naik sekitar $31,82 \%$ untuk indikator lebih gigih, ada 12 siswa atau naik sekitar $6,82 \%$ untuk indikator Menyukai tugas-tugas yang menantang, ada 13 siswa atau naik sekitar $6,82 \%$ untuk indikator Suka berinteraksi dengan orang-orang, ada 15 siswa atau naik sekitar 13,64\% untuk indikator Memiliki usaha yang sangat menonjol, ada 14 siswa atau naik sekitar $25,00 \%$ untuk indikator Tidak suka membuangbuang waktu, ada 9 siswa atau naik sekitar 9,09\% untuk indikator Selalu mempertahankan pendapat yang dianggapnya benar. d. Ada 9 indikator untuk kriteria sangat kurang atau sebesar $50,00 \%$ dari 18 indikator yang ada. Pada kriteria ini terjadi penurunan jumlah indikator dari awal kegiatan observasi sebelum dilakukan tindakan dengan jumlah siswa yang mengalami peningkatan mencapai 5 siswa atau naik sekitar 6,82\% untuk indikator Puas terhadap nilai sebagai hasil usaha sendiri, 6 siswa atau naik sekitar 4,54\% untuk indikator Penuh inisiatif, 7 siswa atau naik sektiar $6,81 \%$ untuk indikator penuh produktif, 6 siswa atau naik sektiar 9,09\% untuk indikator Penuh inisiatif, 5 siswa atau naik sekitar $6,82 \%$ untuk indikator Lebih tangguh dalam mengerjakan suatu tugas, ada 8 siswa atau naik sekitar $2,28 \%$ untuk indikator Selalu menyelesaikan tugas lebih cepat, ada 5 siswa atau naik sekitar 6,82\% untuk indikator Memiliki semangat yang tinggi, ada 8 siswa atau naik sekitar $6,82 \%$ untuk indikator Tidak menyelesaikan tugas setengah-setengah.

Berdasarkan data di atas dapat diketahui bahwa ada 9 indikator yang berada pada taraf sangat kurang, untuk itu peneliti tetap melanjutkan kegiatan ini agar semua indikator bisa mencapai taraf persentase yang telah ditetapkan. 
Pada kegiatan di siklus II, tindakan dilakukan peneliti bersama guru kelas dengan menerapkan metode penguatan positif berupa hadiah yang bertujuan untuk meningkatkan motivasi berprestasi siswa pada pelajaran matematika. Pada kegiatan ini peneliti menerapkan materi Hubungan Satuan Panjang.

$$
\text { Menyampaikan konsep }
$$

Hubungan Satuan Panjang melalui metode penguatan positif yang bertujuan untuk meningkatkan motivasi berprestasi siswa. Dalam metode penguatan positif ini, siswa akan termotivasi, aktif sehingga akan berdampak pada hasil belajar siswa dan membantu siswa mengetahui apa yang harus dan apa yang tidak harus dilakukan dalam kegiatan pembelajaran.

Kegiatan yang dilakukan
untuk peningkatan motivasi
berprestasi siswa dalam bentuk
mandiri adalah sebagai berikut:

a. Memberikan contoh-contoh soal dan penyelesaiannya mengenai satuan panjang dalam pengukuran.

b. Meminta siswa untuk mengerjakan soal yang diberikan guru dan pembahasan dilakukan secara bergantian, siswa diminta maju kedepan kelas untuk mengerjakannya. Hal ini dimaksudkan untuk membuat siswa merasa puas terhadap nilai yang dicapainya dan sebagai penghargaan atas usahanya sendiri serta tanggung jawab terhadap tugas yang diberikan.

c. Memberikan penguatan positif dengan segera yakni berupa hadiah-hadiah sederhana (alat-alat tulis) yang diberikan kepada siswa yang berani mengerjakan ke depan kelas dan yang memiliki nilai yang tinggi.

Kegiatan yang dilakukan untuk meningkatkan hasil belajar siswa dalam bentuk mandiri dengan cara memberikan tes berupa soal dikerjakan secara mandiri yang akan dinilai oleh pengajar.

Pada kegiatan ini peneliti merefleksi dan mengevaluasi semua tahap kegiatan yang telah dilakukan mulai dari pelaksanaan kegiatan tindakan hingga observasi.

Dari observasi guru di atas menggunakan alat peraga pada siklus II di atas, dapat dilihat :

a. Ada 5 indikator guru yang memperoleh nilai A dari 6 indikator yang ada, yaitu pada indikator menggunakan macammacam penguatan positif yang bersifat verbal, yang bersifat non verbal, dapat memberikan penguatan positif dengan segera, memilih hadiah yang bermanfaat untuk kelangsungan belajar siswa dan dapat menyajikan konsep matematika dengan baik.

b. Hanya ada 1 indikator yang memperoleh nilai $\mathrm{B}$ dari 6 
indikator yang ada, yaitu diberikan secara sederhana dan tidak mahal.

Dari lembar observasi guru dapat disimpulkan bahwa guru sudah mulai dapat memfungsikan penguatan positif dengan baik. Dari data hasil observasi pada siklus II di atas dapat diketahui bahwa hasil belajar siswa Kelas VI berdasarkan indikator yang telah ditentukan bisa dibilang cukup memadai, hal ini dapat dilihat dari:

a. Ada 5 indikator yang masuk kriteria sangat baik atau sebesar $27,77 \%$ dari 18 indikator yang ada. Jumlah indikator mengalami peningkatan pada kriteria ini dari awal kegiatan observasi setelah dilakukan tindakan. Jumlah siswa mengalami perubahan cukup meningkat dari sebelum tindakan yaitu menjadi 38 siswa atau naik sekitar $36,36 \%$ untuk indikator untuk indikator Energik, ada 36 siswa atau naik sekitar 68,45\% untuk indikator Suka bertindak, ada 37 siswa atau naik sekitar $56,82 \%$ untuk indikator Menyukai tugas-tugas yang menantang, ada 39 siswa atau naik sektiar 2,27\% untuk indikator Bertanggung jawab terhadap tugas yang diberikan dan ada 39 siswa atau naik 59,09\% untuk indikator Suka berinteraksi dengan orang-orang.

b. Ada 10 indikator untuk kriteria baik atau sebesar $55,55 \%$ dari 18 indikator yang ada. Jumlah indikator mengalami peningkatan pada kriteria ini dari awal kegiatan observasi sebelum dilakukan tindakan. Jumlah siswa yang mengalami peningkatan dari sebelum tindakan yaitu 35 siswa atau naik sekitar 56,81\%, untuk indikator Kreatif, 34 siswa atau naik sekitar 40,91\% untuk indikator Lebih gigih, 35 siswa atau naik sekitar $68,11 \%$ untuk indikator Lebih tangguh dalam mengerjakan suatu tugas, ada 32 siswa atau naik sektiar 54,54\% untuk indikator Selalu menyelesaikan tugas lebih cepat, ada 34 siswa atau naik sekitar 43,18\% untuk indikator Memiliki usaha yang sangat menonjol, ada 30 siswa atau naik sekitar $36,37 \%$ untuk indikator Tidak suka membuang-buang waktu, ada 29 siswa atau naik sekitar 54,54\% untuk indikator Memiliki semangat yang tinggi, ada 35 siswa atau naik sekitar $61,36 \%$ untuk indikator Tidak cepat putus asa, ada 29 siswa atau naik sekitar $45,45 \%$ untuk indikator Selalu mempertahankan pendapat yang dianggapnya benar dan 28 siswa atau naik sekitar 52,27\% untuk indikator Tidak menyelesaikan tugas setengah-setengah.

c. Ada 3 indikator untuk cukup atau sebesar 16,66\% dari 18 indikator yang ada. Jumlah indikator mengalami peningkatan pada 
Oike Naibaho: Pemberian Penguatan Positif ..

kriteria ini dari awal kegiatan observasi setelah dilakukan tindakan. Jumlah siswa yang mengalami perubahan cukup meningkat dari sebelum tindakan yaitu 20 siswa atau naik sekitar $34,09 \%$ untuk indikator Puas terhadap nilai sebagai hasil usaha sendiri, 25 siswa atau naik sekitar 40,91\% untuk indikator Produktif dan 20 siswa atau naik sekitar $36,36 \%$ untuk indikator Penuh inisiatif.

\section{Pembahasan}

Dari hari observasi di atas dapat dilihat bahwa semua indikator yang ada telah mengalami peningkatan yang cukup signifikan. Dari 18 indikator ada 5 indikator yang sangat mengalami peningkatan hingga mencapai kriteria sangat baik yaitu indikator Energik, Suka bertindak, Menyukai tugas-tugas yang menantang, Suka berinteraksi dengan orang-orang dan ada indikator Suka berinteraksi dengan orang-orang. Pada indikator energik peningkatan ini dapat terjadi dikarenakan peneliti selalu memberikan penguatan yang berupa hadiah dan siswa selalu energik untuk mengeluarkan semua ide-idenya tanpa memberikan batasan, seperti memberikan alat-alat tulis.

Peningkatan juga terjadi pada indikator suka bertindak ini dikarenakan peneliti menghargai tindakan yang dilakukan oleh siswa tanpa menyinggung perasaan atau mempermalukan siswa tersebut.

Peningkatan juga terjadi pada indikator Suka bertindak, ini dikarenakan peneliti selalu memberikan pujian kepada siswa yang lebih cepat menyelesaikan tugas seperti memberi nilai dan mengucapkan "bagus sekali", "baik sekali", "kamu pintar" dan lain-lain.

Faktor penghambat pada penelitian ini adalah masih belum siapnya siswa menghadapi situasi pembelajaran yang baru diterapkan oleh peneliti baik itu dalam hal mengemukakan ide, selalu maju ke depan kelas dalam mengerjakan tugas, mendengarkan instruksi yang diberikan oleh peneliti dan kurang siapnya peneliti dalam menghadapi situasi yang baru.

Faktor pendukung selama penelitian ini berlangsung adalah siswa memiliki kemauan yang kaut dalam mengikuti kegiatan pembelajaran dan beradaptasi dengan peneliti dan banyak siswa yang senang dalam mengikuti pembelajaran.

\section{SIMPULAN}

Berdasarkan hasil dan pembahasan penelitian tindakan kelas yang dilakukan dengan pemberian penguatan positif pada pembelajaran matematika di Kelas VI SD Negeri 060819 Medan Kota. 
a. Kesimpulan Hasil

Pemberian penguatan positif (hadiah) berupa alat-alat tulis pada proses pembelajaran matematika dapat meningkatkan motivasi untuk prestasi belajar siswa.

b. Kesimpulan Proses

Pemberian penguatan positif pada pembelajaran matematika dapat meningkatkan keaktifan siswa, keantusiasan mengikuti pembelajaran matematika serta dapat meningkatkan angka-angka prestasinya.

\section{DAFTAR RUJUKAN}

Hamalik, Drs. Oemar, 2007. Kurikulum dan Pembelajaran. Bandung: Bumi Aksara.

Jatmiko, 2003. Penelitian Tindakan Kelas. Jakarta: Departemen Pendidikan dan Kebudayaan.

Purwanto, Drs. Ngalim, MP, 2006. Psikologi Pendidikan. Bandung: REMAJA ROSDAKARYA.

Sardiman A.M, 2006. Interaksi Motivasi Belajar. Jakarta: Raja Grafindo Persada. 